ks. Jan Dyduch

Uniwersytet Papieski Jana Pawła II w Krakowie

\title{
Posługa nauczania
}

\section{w uchwałach II Synodu Katowickiego}

II Synod Katowicki rozpoczął się 25 listopada 2012 r., a zakończył się 20 listopada 2016 r. Zarówno rozpoczęcie, jak i zakończenie Synodu wyznaczyła uroczystość Chrystusa Króla, patrona archidiecezji katowickiej. II Synod Katowicki nawiązuje do I Synodu Diecezji Katowickiej (1972-1975), który dokonał recepcji postanowień II Soboru Watykańskiego. Uchwały II Synodu Katowickiego stanowią pogłębioną asymilację nauczania Vaticanum II. Wskazuje na to także częste przywoływanie dokumentów Soboru Watykańskiego II, w szczególności jako podstawy interpretacji wskazań synodalnych ${ }^{1}$. Trzeba przypomnieć, iż utworzona 10 lutego 1925 r. diecezja katowicka (śląska) została przekształcona 25 marca 1992 r. w archidiecezję katowicką (śląską).

Uchwały II Synodu Katowickiego mają przygotować Kościół katowicki na jubileusz stulecia jego powstania. Ma on być obrazem biblijnego ideału Kościoła: „Jak pisze św. Paweł, sam Chrystus - Głowa Kościoła, chce go mieć jako «chwalebny, nie mający skazy czy zmarszczki, czy czegoś podobnego, lecz aby był święty i nieskalany» $\left(\mathrm{Ef}_{5}, 25\right)$ i do tego biblijnego ideału Kościoła, który ma być Chrystusowy i przez to wiarygodny, trzeba nam dążyć”’. Niniejszy artykuł zamierza, przynajmniej w zarysie, ukazać program posługi nauczania w Kościele katowickim oparty na uchwałach II Synodu Archidiecezji Katowickiej.

1 W. Skworc, Wstuchani w Ducha. Uchwały II Synodu Archidiecezji Katowickiej, Katowice 2016 [dalej: II SAK], Wprowadzenie.

${ }^{2}$ II SAK, Wprowadzenie. 


\section{Głoszenie Słowa Bożego}

II Synod naucza: „Idźcie na cały świat i głoście Ewangelię wszelkiemu stworzeniu (Mk 16, 15) - polecił Zmartwychwstały Chrystus Apostołom. Odpowiedź na to wezwanie wymaga nieustannej odnowy przepowiadania Słowa Bożego"3. Przepowiadanie Słowa Bożego to zadanie wszystkich wyznawców Chrystusa: biskupów, prezbiterów, diakonów, zakonników i wiernych świeckich. Mają głosić Ewangelię zarówno słowem, jak i świadectwem życia, gdyż są sługami Słowa. Skuteczność głoszenia zależy nie tylko od mocy Bożej obecnej w Słowie, lecz także od świadectwa życia sługi Słowa ${ }^{4}$. Głosiciel Słowa Bożego jako jego sługa jest narzędziem Jezusa Chrystusa, Proroka i Nauczyciela. Ma być narzędziem sprawnym oraz skutecznym, dlatego swoje przepowiadania powinien uwiarygodniać świadectwem życia. Aktualnie słuchacze Słowa oceniają nie tylko treść przekazu, ale pytają: kim on jest? jakim jest świadkiem? ${ }^{5}$

Do tego świadectwa wzywa II Synod Katowicki: „Realizując posługę prorocką (martyria), Kościół katowicki powinien skoncentrować się na pogłębianiu formacji osób duchownych, świeckich i konsekrowanych, tak aby [...] stawały się świadkami Chrystusa wobec braci i sióstr" ${ }^{6}$. Słusznie Synod zauważa, iż owocne dawanie świadectwa Chrystusowi wymaga odpowiedniej formacji.

Dawanie świadectwa Chrystusowi jest konieczne w prowadzeniu każdej działalności ewangelizacyjnej, których nieodłącznym elementem jest głoszenie Słowa Bożego. Wydaje się jednak, iż owo świadectwo jest szczególnie palącym problemem w nowej ewangelizacji. Naucza Synod: „Jedną z form realizacji tego posłannictwa (ewangelizacji) są działania określone mianem nowej ewangelizacji, których celem - szczególnie w warunkach polskiego Kościoła - jest dotarcie z dobrą nowiną do osób, które wprawdzie przyjęły część sakramentów inicjacji chrześcijańskiej w Kościele katolickim, ale nie odpowiedziały na nie osobistą wiarą i świadomą decyzją pójścia za Chrystusem we wspólnocie Kościoła”. Tym zagubionym trzeba głosić Ewangelię z nową gorliwością, nowymi metodami i z zastosowaniem nowych środków

\footnotetext{
II SAK, n. 237.

4 Por. K. Wojtyła, U podstaw odnowy, Kraków 1972, s. 215-216.

5 Por. G. Siwek, Kaznodzieja jako świadek, [w:] Stuga słowa, red. W. Przyczyna, Kraków 1997,

6 II SAK, n. 4.

7 II SAK, n. 313 .
} s. $83-108$. 
przekazu. Jest to naglące zadanie możliwe do wykonania jedynie wówczas, gdy jest poparte gorliwym świadectwem życia ${ }^{8}$.

W przepowiadanie Słowa Bożego należy włączyć wiernych świeckich w ramach obowiązujących przepisów prawa kanonicznego i uchwał synodalnych. Są wezwani do współorganizowania rekolekcji ewangelizacyjnych, do uczestnictwa w niedzielach oraz tygodniach biblijnych, w nabożeństwach i wykładach połączonych z czytaniem Biblii. Wzywa się ich także do zaangażowania w głoszeniu konferencji, katechez i wyjaśnianiu Słowa Bożego?.

W Kościele katowickim przepowiadanie Słowa Bożego charakteryzuje się: chrystocentryzmem, obecnością treści biblijnych, odniesieniem egzystencjalnym, unikaniem homilii politykujących i głoszeniem homilii o tematyce społeczno-politycznej ${ }^{10}$. Problematyka społeczna jest szeroko włączona w działalność ewangelizacyjną, ukazującą, jak chrześcijanin ma łączyć Ewangelię z życiem codziennym. Nauczanie społeczne Kościoła jest zakorzenione w Ewangelii, która je inspiruje oraz wyznacza drogi społecznym praktykom wspólnoty wierzących ${ }^{11}$.

Głoszenie Słowa Bożego urzeczywistnia się w dwóch zasadniczych formach: homilii i kazaniu tematycznym. Głoszenie homilii jest obowiązkowe w niedziele i święta nakazane, zgodnie z prawem powszechnym (por. kan. 767 KPK). $\mathrm{Z}$ zastrzeżeniem, iż stanowczo nie może być ona zastąpiona komunikatem Konferencji Biskupiej i arcybiskupa katowickiego, które mają być umieszczone w ogłoszeniach duszpasterskich. Homilia ma być głoszona przez celebrującego mszę św. kapłana lub przez duchownego w niej uczestniczącego. Zaleca się, aby codzienna homilia była głoszona we wszystkich kościołach archidiecezji katowickiej oraz udostępniana wiernym po jej wygłoszeniu. Zaleca się także, aby w czasie mszy św. dla rodzin organizowano odrębną liturgię słowa dla dzieci' ${ }^{12}$. Kazania tematyczne mają być głoszone zwłaszcza w czasie rekolekcji i misji parafialnych. Zaleca się włączenie w program rekolekcji i misji konferencji biblijnych, doktrynalnych, moralnych i innych. Zaleca się przeprowadzanie na terenach wielkomiejskich rekolekcji dla większej liczby parafii, na przykład dla całego miasta. Szczególną troską i przygotowaniem

\footnotetext{
8 Por. II SAK, n. 314-326.

9 Por. II SAK, n. 244-245, 29-40, 52-53.

10 Por. II SAK, n. 238.

11 Por. II SAK, n. 422-424, 428.

12 Por. II SAK, n. 246-254.
} 
należy otoczyć rekolekcje szkolne. Należy organizować rekolekcje zamknięte $\mathrm{w}$ domach rekolekcyjnych ${ }^{13}$.

Celem lepszej organizacji głoszenia Słowa Bożego Synod nakazuje powołanie specjalnej komisji: „Należy powołać Archidiecezjalną Komisję do spraw głoszenia Słowa Bożego [...], działającą na rzecz podniesienia poziomu przepowiadania Słowa Bożego i wzmocnienia stałej formacji duchownych"14. Synod zatwierdził i ogłosił jej statut, podkreślając, iż jest organem doradczym arcybiskupa katowickiego, który mianuje jej członków na okres pięciu lat i wyznacza jej przewodniczącego ${ }^{15}$. W aktach wykonawczych II Synodu znajdują się: „Wskazania dotyczące organizacji wielkopostnych rekolekcji szkolnych dla dzieci i młodzieży", które regulują urządzanie corocznych rekolekcji dla tychże grup $^{16}$.

\section{Katechizacja i szkolnictwo}

Drugi Synod Katowicki docenia rolę katechizacji dzieci i młodzieży: „Od katechezy bowiem w dużej mierze zależy wzrost Kościoła w świecie, a jeszcze bardziej rozwój wewnętrzny Kościoła. Z tego względu katecheza była zawsze w Kościele i przez Kościół traktowana jako święty obowiązek, trwałe i niezbywalne prawo"17. Dostrzega on także współczesne zagrożenia katechezy, takie jak: procesy laicyzacyjne i dechrystianizacyjne, tendencje podważające autorytet wychowawczy rodziny i Kościoła, relatywizacja tradycyjnych wartości i zasad ewangelicznych oraz propagowanie negatywnych wzorców przez środki społecznego przekazu. Jako przeciwdziałanie temu wymienia uaktywnienie katechezy w rodzinie i parafii, katechezę dorosłych i rozbudowanie parafialnego duszpasterstwa dzieci i młodzieży ${ }^{18}$. Synod postanawia wzmocnić i poszerzyć organizację duszpasterstwa katechetycznego w archidiecezji. W tym celu nakazuje powołać Archidiecezjalną Szkołę Katechetów Parafialnych dla przygotowania wiernych świeckich do prowadzenia katechezy w parafiach. Zarządza również ustanowienie Rady Wydziału Katechetycznego, która ma inspirować

13 Por. II SAK, n. 255-262.

14 II SAK, n. 240.

15 Por. Statut Archidiecezjalnej Komisji do spraw głoszenia Słowa Bożego, [w:] II Synod Archidiecezji Katowickiej, Akty wykonawcze, Wiadomości archidiecezjalne, Organ Urzędowy Archidiecezji Katowickiej, Suplement 2016 [dalej: II SAK - Suplement], s. 7-8.

16 Por. II SAK - Suplement, s. 114-115.

17 II SAK, n. 263.

18 Por. II SAK, n. 264-266. 
i koordynować pracą katechetyczną w archidiecezji, czuwać nad wypełnianiem zadań katechetyczno-wychowawczych i nad przygotowaniem programów oraz podręczników katechetycznych, a także ściśle współpracować z Wydziałem Katechetycznym ${ }^{19}$.

Synod ogłosił specjalny dokument poświęcony zadaniom i organizacji pracy katechetów świeckich: „Status katechety świeckiego (nauczyciela religii) w Archidiecezji Katowickiej”. Katechetę powołuje i odwołuje arcybiskup katowicki, udzielając mu misji kanonicznej lub ją anulując. Katecheta ściśle współpracuje $\mathrm{z}$ proboszczem, wspierając go także w parafialnej pracy katechetycznej, zharmonizowanej z planem pracy w szkole. Katecheta powstrzymuje się od przynależności do związków zawodowych działających na terenie szkoły, a w swojej działalności kieruje się zasadami katolickiej nauki społecznej. Katecheta uczestniczy w formacji intelektualnej, duchowej i duszpasterskiej organizowanej w diecezji ${ }^{20}$.

Synod zobowiązuje wszystkich katechetów, nie tylko świeckich, do stałej formacji: „Katecheci pełniący posługę na terenie Archidiecezji Katowickiej zobowiązani są do uczestnictwa w stałej formacji intelektualnej i duchowej organizowanej przez Wydział Katechetyczny, we współpracy z Wydziałem Teologicznym Uniwersytetu Śląskiego"21. Wydział Katechetyczny w imieniu i z polecenia arcybiskupa katowickiego kieruje formacją katechetów w diecezji. Ma on opracować program formacji podstawowej i stałej katechetów parafialnych, jak również we współpracy z Wydziałem Duszpasterstwa Rodzin zająć się katechezą dorosłych. Współpraca ta dotyczy zarówno katechezy dla rodziców, których dzieci przygotowują się do przyjęcia Najświętszej Eucharystii, sakramentu pokuty i sakramentu bierzmowania, jak i tych dorosłych, którzy sami przygotowują się do przyjęcia sakramentów inicjacji chrześcijańskiej ${ }^{22}$.

Nauczanie religii w szkole należy skoordynować z duszpasterstwem dzieci i młodzieży w parafii: „Mając na uwadze zacieśnienie współpracy pomiędzy parafią a szkołą, zobowiązuje się proboszcza do osobistego kontaktu z dyrektorami placówek oświatowych znajdujących się na terenie parafii, celem uzgodnienia projektu organizacyjnego pracy nauczyciela religii oraz harmonogramu duszpasterstwa parafialnego $\mathrm{z}$ planem pracy w szkole" ${ }^{\prime 23}$. Wydaje

\footnotetext{
19 Por. II SAK, n. 267-269.

${ }^{20}$ Por. II SAK - Suplement, s. 88-91.

21 II SAK, n. 305.

${ }^{22}$ Por. II SAK, n. 307, 273-279.

${ }^{23}$ II SAK, n. 296.
} 
się, iż nawiązanie takich kontaktów między szkołą a parafią przysłuży się dobru wspólnemu danej miejscowości. Zerwane więzy między szkołą a parafią, czego dokonał system komunistyczny w czasach PRL, nie zostały jeszcze wystarczająco skutecznie zrekonstruowane. Stąd program naprawy stosunków społecznych w obrębie miejscowości jest bardzo pożądany.

Wydaje się, że współpracy między szkołą a parafią może wydatnie przysłużyć się reaktywowanie posługi stałego katechety. II Synod postanawia: „Wydział Katechetyczny jest zobowiązany wskazywać kandydatów do podjęcia w Archidiecezji Katowickiej posługi stałego katechety oraz szkoły wymagającej takiej

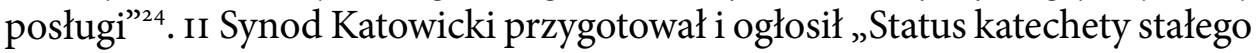
w Archidiecezji Katowickiej”25. Takim stałym katechetą może zostać prezbiter, który posiada predyspozycje i doświadczenie w pracy duszpasterskiej z młodzieżą szkół średnich. Stały katecheta, zwany także prefektem, zostaje mianowany przez arcybiskupa katowickiego na okres pięciu lat z możliwością przedłużenia na kolejne pięciolecia, w porozumieniu z Wydziałem Katechetycznym. Prefektem może zostać kapłan będący nauczycielem dyplomowanym albo przynajmniej przygotowujący się na to stanowisko. Prefekt powinien pełnić obowiązki dydaktyczne w wymiarze co najmniej etatu nauczyciela w rozumieniu prawa oświatowego. Prefekt jest duszpasterzem uczniów i nauczycieli szkoły, w której pełni swoją funkcję. Status określa także sprawy bytowe prefekta i jego obowiązki w parafii zamieszkania. Może zostać odwołany przez arcybiskupa katowickiego, na wniosek Wydziału Katechetycznego, na podstawie negatywnej oceny jego pracy przedstawionej przez wizytatora katechetycznego lub dyrektora szkoły ${ }^{26}$.

Drugi Synod Katowicki docenia znaczenie szkół katolickich, stwierdzając ich pozytywny wpływ na rozwój życia religijnego uczniów i nauczycieli. W związku z tym kieruje on apel do parafii, zgromadzeń zakonnych i do stowarzyszeń katolików świeckich o zakładanie i prowadzenie przedszkoli oraz szkół katolickich na wszystkich poziomach kształcenia. Troska o te przedszkola i szkoły w szczególniejszy sposób zostaje powierzona Wydziałowi Katechetycznemu ${ }^{27}$. Drugi Synod przygotował i ogłosił „Wskazania dotyczące szkół katolickich w Archidiecezji Katowickiej"28.

\footnotetext{
${ }^{24}$ II SAK, n. 300.

${ }^{25}$ II SAK - Suplement, s. $85-87$.

${ }^{26}$ Por. II SAK - Suplement, s. 86-87.

${ }^{27}$ II SAK, n. 310-312.

${ }^{28}$ II SAK - Suplement, s. 133-134.
} 
Wskazaniom II Synodu nie jest obce istnienie i działalność Wydziału Teologicznego Uniwersytetu Śląskiego. Nawiązano do niej przede wszystkim, formułując wskazania o formacji katechetów i o promowaniu nauki społecznej Kościoła oraz o docieraniu $\mathrm{z}$ nią do szerokich kręgów archidiecezji ${ }^{29}$. Wydaje się, że wskazane byłoby szersze ukazanie roli Wydziału Teologicznego w strukturze i posłannictwie Kościoła katowickiego. Współczesny obraz Kościoła nie jest pełny bez ukazania znaczenia wyższych uczelni, w szczególności uniwersytetów kościelnych i wydziałów teologicznych, dla ewangelizowania nauki, oświaty i kultury. Nie można zapominać, iż uniwersytety zrodziły się w łonie Kościoła katolickiego ${ }^{30}$.

\section{Dialog misyjny i ekumeniczny}

Sobór Watykański II naucza: „Pielgrzymujący Kościół z natury swojej jest misyjny, ponieważ bierze początek z misji Syna i Ducha Świętego, zgodnie z zamysłem Boga Ojca" ${ }^{31}$. Kościół, będąc posłuszny swemu Założycielowi, chce głosić orędzie zbawcze wszystkim ludziom, aby mogli osiągnąć zbawienie. Dlatego cały Kościół jest misyjny, a dzieło ewangelizacji jest podstawowym zadaniem Ludu Bożego ${ }^{32}$. W te wskazania włącza się II Synod: „Dlatego Kościół katowicki uznaje propagowanie misji za jeden $\mathrm{z}$ kluczowych elementów działalności duszpasterskiej w parafiach, stowarzyszeniach, grupach - szczególnie w tych, które skupiają młodzież”33.

Drugi Synod planuje ożywić dotychczasową działalność misyjną archidiecezji katowickiej, zmierzając do wypracowania jednolitego systemu promocji misji, który by dokonał: pogłębienia duchowości misyjnej, rozwoju i wzrostu świadomości misyjnej wśród wiernych archidiecezji, formacji animatorów misyjnych, rozbudowy powołań misyjnych i poprawy skuteczności pomocy misjonarzom ${ }^{34}$. Realizację powyższego programu powierza się powołanemu przez Synod w strukturach kurii metropolitalnej Wydziałowi do spraw Misji. Synod nakazuje ustanowienie w każdym dekanacie dekanalnego zespołu

29 Por. II SAK, n. 303-309, 438.

3o Por. J. Dyduch, Posłannictwo uniwersytetów w świetle dokumentów kościelnych, „Prawo Kanoniczne" 38 (1995) nr 1-2, s. 79-9o.

31 Sobór Watykański II, dekret Ad gentes divinitus, n. 2.

${ }^{32}$ Por. Sobór Watykański II, dekret Ad gentes divinitus, n. 48, 38.

33 II SAK, n. 327.

34 Por. II SAK, n. 329. 
misyjnego, któremu przewodniczy dziekan, zaś w parafiach należy tworzyć parafialne lub szkolne koła misyjne. Istniejący od 2013 r. program „Aniołowie Misji” należy uaktywnić. Drugi Synod ogłasza „Regulamin Wydziału do spraw Misji”35. Przywołany program „Aniołowie Misji” jest długofalowym autorskim planem niesienia pomocy misjonarzom archidiecezji katowickiej, zarówno duchowej - przez modlitwę, jak i materialnej - przez wpłaty. Pozyskane środki są przeznaczone na realizację projektów ewangelizacyjnych, sakralnych, edukacyjnych i rozwojowych, kierowanych przez poszczególnych misjonarzy ${ }^{36}$.

W spomniany wyżej „Regulamin Wydziału do spraw Misji” określa strukturę i zadania Wydziału do spraw Misji. Wydział ten przede wszystkim promuje, animuje i koordynuje działalność misyjną Kościoła katowickiego, stale współpracuje z misjonarzami, wspiera ich materialnie oraz co trzy lata organizuje rekolekcje dla misjonarzy-prezbiterów. Buduje także świadomość misyjną wiernych archidiecezji, szczególnie przez propagowanie idei misyjnych i modlitwy za misje i o powołania misyjne, prowadzi formację animatorów misyjnych, pomaga w zakładaniu i funkcjonowaniu parafialnych i szkolnych kół misyjnych oraz promuje misje w mediach. Wydział koordynuje również współpracę różnych podmiotów zajmujących się w archidiecezji misjami oraz zarządza Funduszem Misyjnym Archidiecezji. Wydziałem zarządza dyrektor powołany przez arcybiskupa katowickiego na pięcioletnią kadencję. Współpracuje on z dyrektorami Papieskich Dzieł Misyjnych ${ }^{37}$.

Działalność misyjna Kościoła katowickiego włączona jest w wieloraki jego dialog. Owocna działalność misyjna nie jest możliwa bez dialogu. Dialog jest jej narzędziem. W ten dialog jest włączona także działalność ekumeniczna. Drugi Synod naucza: „Chrystus uczy nas szacunku wobec każdego człowieka. Kościół stąd wywodzi między innymi zobowiązanie do podstawy dialogu, w której wyrażają się miłość bliźniego i szacunek dla prawdy" ${ }^{38}$. Udział w dialogu ekumenicznym jest zadaniem wszystkich chrześcijan, wyznaczonym przez Chrystusa. Modlił się On: „[...] aby wszyscy stanowili jedno”. To program wyznaczony wszystkim wyznawcom Chrystusa i to także droga Kościoła ${ }^{39}$.

Drugi Synod akcentuje dialog między Kościołami i wspólnotami chrześcijańskimi. Wielokulturowa ziemia śląska jest regionem pokojowego i harmonijnego

\footnotetext{
35 Por. II SAK, n. 330-333.

${ }^{36}$ Por. II SAK, przypis 177.

37 Por. II SAK - Suplement, s. 175-177.

${ }^{38}$ II SAK, n. 485.

39 Por. II SAK, n. 486.
} 
współistnienia osób różnych wyznań i różnych Kościołów chrześcijańskich. Kościół katowicki prowadzi z nimi ekumeniczną współpracę na płaszczyźnie duchowej, doktrynalnej i praktycznej. Drugi Synod podkreśla potrzebę dialogu chrześcijan z wyznawcami innych religii niechrześcijańskich. Zalicza go do istotnego elementu chrześcijańskiej podstawy wobec świata. W dialogu tym chodzi głównie o lepsze wzajemne poznanie i szacunek dla budowania pokoju społecznego, prowadzenia wspólnych akcji charytatywnych i kulturalnych oraz troski o wolność religijną ${ }^{40}$.

Drugi Synod powołuje Centrum Ekumenizmu i Dialogu Międzyreligijnego przygotowującego i prowadzącego działalność ekumeniczną i międzyreligijną wspólnie z Archidiecezjalną Komisją Ekumeniczną i Dialogu Międzyreligijnego. Synod wyznacza także program formacji oraz współpracy ekumenicznej i międzyreligijnej, jej rozwoju w oparciu o dotychczasowe doświadczenia i praktyki Kościoła katowickiego. Wzywa również do udziału w tej współpracy Wydział Katechetyczny i Wydział Teologiczny Uniwersytetu Śląskiego ${ }^{41}$.

\section{Środki społecznego przekazu}

Sobór Watykański II naucza: „Kościół katolicki został ustanowiony przez Chrystusa Pana, aby nieść zbawienie wszystkim ludziom, i z tego względu zobowiązany jest do głoszenia Ewangelii, dlatego uznaje on, że do jego obowiązków należy głoszenie orędzia zbawienia, również za pomocą środków społecznego przekazu i pouczania ludzi o właściwym ich wykorzystywaniu" ${ }^{42}$. Kościół głosi zbawczą Ewangelię, posługując się wszelkimi dostępnymi środkami służącymi zbawieniu ludzi, gdyż jego najwyższym prawem jest salus animarum - „zbawienie dusz” (por. kan. $1752 \mathrm{KPK}$ ). Konsekwencją jest prawo wrodzone (ius nativum) przysługujące Kościołowi - do posiadania i używania środków społecznego przekazu. Prawo to sięga natury Kościoła i dlatego jego realizowanie spoczywa zarówno na pasterzach, jak i pozostałych wiernych. Pasterze mają obowiązek kierowania wiernymi i pouczania ich o właściwym używaniu środków przekazu dla osiągnięcia własnej doskonałości i zbawienia. Szczególnym zadaniem wiernych świeckich jest kształtowanie tychże środków w duchu humanizmu i chrześcijaństwa ${ }^{43}$. Wśród środków przekazu, które

\footnotetext{
40 Por. II SAK, n. 487-489.

${ }^{41}$ Por. II SAK, n. 490-506.

${ }^{42}$ Sobór Watykański II, dekret Inter mirifica, n. 3.

${ }^{43}$ Por. Sobór Watykański II, dekret Inter mirifica, n. 3-4.
} 
w ostatnich dziesiątkach lat bardzo się rozwinęły, ważną pozycję zajmuje nadal słowo pisane. Dlatego też jest ono otoczone szczególną troską pasterzy Kościoła ${ }^{44}$.

Nauczanie soborowe, a także dokumenty kościelne następnych lat dotyczące środków przekazu, dostrzegają zarówno korzyści, jak i zagrożenia z nimi związane. Stąd ustawiczny apel i troska o formację tak twórców, jak i odbiorców treści społecznego przekazu oraz o ich wykorzystanie w ewangelizacji. W tę troskę włącza się II Synod Katowicki, który naucza: „Współczesne środki społecznego przekazu, jako jeden ze znaków czasu, niewątpliwie mogą stanowić skuteczne narzędzie w szerzeniu Ewangelii, dlatego Kościół pragnie z nich korzystać" 45 .

Kościół katowicki troszczy się o rozwój własnych środków społecznego przekazu i instytucji służących apostolstwu słowa. W działalność medialną aktualnie angażują się: Instytut Gość Media, Biuro Prasowe Archidiecezji Katowickiej, Księgarnia św. Jacka, Drukarnia Archidiecezjalna oraz miesięcznik „Apostolstwo Chorych”. Działalność medialną o zróżnicowanym stopniu aktywności prowadzą również parafie, ruchy i stowarzyszenia kościelne, wydając gazetki parafialne, redagując strony internetowe i kanały w mediach społecznościowych ${ }^{46}$.

Przywołane środki przekazu winny w Kościele katowickim budować więzi społeczne i wspólnotowe oraz być narzędziem służącym do realizacji, pielęgnowania i odnawiania misji chrześcijan w Kościele i świecie. Katolicy tworzący i działający w mediach są odpowiedzialni za wspieranie innych w formacji ewangelicznej, w pogłębianiu ich wiary, w nawiązywaniu więzi wspólnotowych oraz w dialogu. Winni oni również odznaczać się rzetelnością, szacunkiem dla odbiorców, ewangelicznym językiem pojednania i życzliwości oraz służebną postawą wyrażającą się w poszukiwaniu dobra wspólnego także z osobami o odmiennych poglądach. Do realizacji tych zadań trzeba przygotowywać należycie nowe zastępy pracowników oraz doskonalić struktury organizacyjne i infrastruktury archidiecezjalnych mediów. W tej dziedzinie jest konieczny rozwój tak zwanych nowych mediów. Rozumie się przez nie media związane z nowymi technologiami cyfrowymi - przede wszystkim media społecznościowe ${ }^{47}$.

\footnotetext{
${ }^{44}$ Por. E. Sztafrowski, Podręcznik Prawa Kanonicznego, t. 3, Warszawa 1986, s. 79-89.

45 II SAK, n. 342.

${ }^{46}$ Por. II SAK, n. 343.

47 Por. II SAK, n. 344-346.
} 
Przywołany Instytut Gość Media stanowi kościelną osobę prawną, składającą się z dwóch podmiotów: Wydawnictwo Kurii Metropolitalnej „Gość Niedzielny” oraz Radio eM. Ma on troszczyć się o tradycyjne media, a także skoncentrować działalność na przestrzeni internetowej i na "nowych mediach”, tak aby wytworzone treści tekstowe, dźwiękowe, graficzne i filmowe trafiały do jak największej grupy odbiorców i były starannie dobierane odnośnie do merytorycznej treści i zgodności z nauczaniem Kościoła. Zarządzenia i zalecenia II Synodu określają strukturę i zadania Instytutu Gość Media ${ }^{48}$.

Drugi Synod wzywa do współpracy Instytutu z Biurem Prasowym Archidiecezji Katowickiej, celem utworzenia silnego centrum informacyjnego o zasięgu lokalnym. Synod postanawia także zlecić przebudowę strony internetowej Archidiecezji Katowickiej tak, by miała charakter oficjalny i zawierała dokumenty oraz informacje o najważniejszych wydarzeniach Kościoła katowickiego. Zarządzono, aby każda parafia, a także wszystkie ruchy wspólnoty, bractwa i stowarzyszenia o wymiarze archidiecezjalnym posiadały i na bieżąco aktualizowały własne strony internetowe. Czuwanie nad przywołanymi mediami elektronicznymi powierzono proboszczom i moderatorom wspomnianych struktur $^{49}$. Drugi Synod zaleca kościelnym środkom przekazu systematyczne i metodyczne upowszechnianie nauki społecznej Kościoła, jej popularyzowanie przez media parafialne, takie jak gazetki parafialne czy strony internetowe. W tej działalności należy korzystać z miejscowych zasobów i z materiałów przygotowywanych na szczeblu archidiecezjalnym ${ }^{50}$. Można zauważyć, że II Synod Katowicki przywiązuje wielką wagę do dawnych i nowych środków przekazu społecznego w posłudze nauczania.

\section{Zakończenie}

Drugi Synod Katowicki prezentuje program przygotowania archidiecezji katowickiej do jej wielkiego jubileuszu stulecia istnienia, najpierw jako diecezja od 1925 r., a potem archidiecezja od 1992 r. Ważnym elementem tego programu są wytyczne, zalecenia i zarządzenia Synodu dotyczące posługi nauczania. Jest ona ukazana w oparciu o wskazania Vaticanum II i posoborowych dokumentów kościelnych. Posługa nauczania koncentruje się na przepowiadaniu Słowa Bożego, nauczaniu katechetycznym i szkolnym, dialogu misyjnym

\footnotetext{
48 Por. II SAK, przypis 185 , n. $347-353$.

49 Por. II SAK, n. 353-363.

5o Por. II SAK, n. $439-440$.
} 
i ekumenicznym, z uwzględnieniem środków społecznego przekazu. Wydaje się, że dla zrealizowania tego programu będą potrzebne dodatkowe normy i powołanie nowych instytucji Kościoła katowickiego.

\section{Abstrakt}

Istniejąca od 1925 r. diecezja katowicka, podniesiona w 1992 r. do godności archidiecezji, w przededniu jubileuszu swojego istnienia, dnia 20 listopada 2016 r. przekazała ludowi bożemu Kościoła katowickiego dar w postaci uchwał II Synodu Archidiecezji Katowickiej. Ma on pogłębić rozumienie Soboru Watykańskiego II i ożywić wiarę, nadzieję i miłość wiernych tego Kościoła partykularnego. Ukazane w niniejszym artykule normy dotyczące posługi nauczania w Kościele katowickim jawią się jako narzędzia mogące pomóc $\mathrm{w}$ realizowaniu tego celu.

\section{SŁoWA KLUCzowe}

II Synod Katowicki, przepowiadanie Słowa Bożego, katechizacja, działalność misyjna, ekumenizm, społeczne środki przekazu

\section{Abstract \\ The ministry of teaching in the Second Synod of the Archdiocese of Katowice}

The Diocese of Katowice, in existence since 1925, elevated to the dignity of the archdiocese in 1992, just before its jubilee, on November 20, 2016, gave the People of God of the Katowice Church the gift of the synodal declarations. The declarations in question deepen the understanding of the Second Vatican Council and animate the faith, love, and hope of the Church of Katowice. The paper presents the norms about the teaching of the Church and considers them a useful tool for achieving the goal in question.

\section{KEY WORDS}

the Second Synod of Katowice, preaching, catechesis, missionary activity, ecumenism, means of social communication 


\section{BIBLIOGRAFIA}

\section{Źródła}

Skworc Wiktor, Wstuchani w Ducha. Uchwały II Synodu Archidiecezji Katowickiej, Katowice 2016.

Sobór Watykański II, dekret Inter mirifica.

Sobór Watykański II, dekret Ad gentes divinitus.

II Synod Archidiecezji Katowickiej, Akty wykonawcze, Wiadomości archidiecezjalne, Organ Urzędowy Archidiecezji Katowickiej, Suplement 2016.

\section{Literatura}

Dyduch J., Posłannictwo uniwersytetów w świetle dokumentów kościelnych, „Prawo Kanoniczne" 38 (1995) nr 1-2, s. 79-90.

Siwek G., Kaznodzieja jako świadek, [w:] Sługa słowa, red. W. Przyczyna, Kraków 1997, s. 83-108.

Sztafrowski E., Podręcznik prawa kanonicznego, t. 3, Warszawa 1986.

Wojtyła K., U podstaw odnowy, Kraków 1972. 